\begin{tabular}{|c|c|c|}
\hline institut & $\begin{array}{l}\text { CARADDE: Jurnal Pengabdian Kepada Masyarakat } \\
\text { https://journal.ilininstitute.com/index.php/caradde } \\
\text { Volume 1 | Nomor 2 | Februari |2019 } \\
\text { e-ISSN: } 2621-7910 \text { dan p-ISSN: } 2621-7961 \\
\text { DOI: https://doi.org/10.31960/caradde.v1i2.56 }\end{array}$ & $\begin{array}{l}\text { GuiN } \\
\text { CaragoE } \\
\end{array}$ \\
\hline
\end{tabular}

\title{
Penerapan Teknologi Tepat Guna Pascapanen Dalam Upaya Peningkatan Produktifitas Petani Kopi di Kabupaten Bener Meriah
}

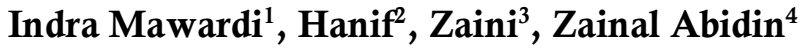

\begin{tabular}{ll}
\hline Keywords : & Abstrak. Penerapan teknologi tepat guna pascapanen kopi \\
Pascapanen kopi; & merupakan salah satu cara untuk meningkatkan nilai \\
Mesin-mesin TTG; & tambah komoditas perkebunan kopi. Kelompok tani BLJ \\
Petani kopi; & Tani (Blang Jorong Tani) dan kelompok tani Buge Mujadi \\
Produktifitas; & adalah dua kelompok tani petani kopi di Desa Petukel Blang \\
& Jorong yang akan menjadi masyarakat mitra kegiatan \\
Corespondensi Author & penerapan TTG. Tujuan dari kegiatan penerapan TTG ini \\
Jurusan Teknik Mesin & adalah untuk meningkatkan produktifitas masyarakat mitra \\
Politeknik Negeri Lhokseumawe & (petani kopi) di Desa Petukel Blang Jorong melalui \\
Lhokseumawe - Aceh & penerapan mesin-mesin TTG pascapanen kopi. Mesin-mesin \\
Email: ddx_72@yahoo.com & yang akan diterapkan nantinya adalah mesin pengupas kulit \\
& buah kopi sistem berjalan, mesin pencuci buah kopi dan \\
History Artikel & mesin huller berjalan. Metode pelaksanaan program dimulai \\
Received: Oktober-2018; & dari survey ke lokasi, sosialisasi program, perancangan dan \\
Reviewed: Desember-2018 & pembuatan mesin-mesin pascapanen kopi, penerapan mesin \\
Accepted: Januari-2019 & yang telah difabrikasi dan evaluasi kegiatan. Dari hasil \\
Published: Februari-2019 & kegiatan telah diproduksi mesin-mesin tepat guna pascapanen \\
& kopi, yang terdiri dari dua unit mesin pengupas kulit kopi \\
& berjalan (pulper mobile), satu unit mesin pencuci biji kopi \\
& type bacth, dan satu unit mesin pengupas biji kopi berjalan \\
& (huller mobile). Petani kopi di Desa Petukel Blang Jorong \\
& Kabupaten Bener Meriah telah mengenal mesin-mesin \\
& teknologi tepat guna pascapanen kopi. Hasil evaluasi \\
& kegiatan menunjukan produktifitas petani kopi mulai \\
& meningkat. Hal ini dapat terlihat dari proses pengolahan kopi \\
& pascapanen yang lebih efektifdan efesien. \\
\hline
\end{tabular}

(i) This work is licensed under a Creative Commons Attribution

4.0 International License

\section{PENDAHULUAN}

Kopi merupakan salah satu penghasil sumber devisa Indonesia, dan memegang peranan penting dalam pengembangan industri perkebunan. Indonesia adalah negara penghasil kopi terbesar ketiga setelah Brazil dan Vietnam. Produksi kopi nasional pada 2014 sebanyak 685 ribu ton atau $8,9 \%$ dari jumlah total produksi kopi global. Produksi kopi robusta sebanyak $76,7 \%$ dari jumlah total produksi nasional tersebut. Sisanya bersumber dari kopi arabika 23,3\%. Volume ekspor kopi robusta Indonesia memiliki prospek yang baik (Chandra, 2013). Dalam kurun waktu 20 tahun luas areal dan produksi perkebunan kopi di Indonesia, khususnya perkebunan kopi rakyat mengalami perkembangan yang sangat signifikan. 
Menurut data dari Asosiasi Eksportir Kopi Indonesia (AEKI), para petani Indonesia bersama dengan kementeriankementerian terkait berencana untuk memperluas perkebunan-perkebunan kopi Indonesia, sambil meremajakan perkebunanperkebunan lama melalui program intensifikasi. Dengan meningkatkan luas perkebunan, produksi kopi Indonesia dalam 10 tahun ke depan ditargetkan untuk mencapai antara 900 ribu ton sampai 1,2 juta ton per tahun (indonesia-investments.com: 2017). Peningkatan produksi kopi juga terjadi di provinsi Aceh, khususnya di kabupaten Aceh tengah, Bener Meriah, dan Gayo Lues. Menurut Thurmizi (2014), produksi kopi Aceh mencapai 48.282 ton dengan luas area 123.746 Ha.

Perkembangan yang cukup pesat tersebut perlu di dukung dengan kesiapan teknologi dan sarana pascapanen yang cocok untuk kondisi petani agar mereka mampu menghasilkan biji kopi dengan mutu seperti yang dipersyaratkan oleh Standard Nasional Indonesia. Adanya jaminan mutu yang pasti, ketersediaan dalam jumlah yang cukup dan pasokan yang tepat waktu serta keberlanjutan merupakan beberapa persyaratan yang dibutuhkan agar biji kopi rakyat dapat dipasarkan pada tingkat harga yang lebih menguntungkan. Untuk memenuhi persyaratan di atas penanganan pascapanen kopi rakyat harus dilakukan dengan tepat waktu, tepat cara dan tepat jumlah seperti halnya produk pertanian yang lain. Buah kopi hasil panen perlu segera diproses menjadi bentuk akhir yang lebih stabil agar aman untuk disimpan dalam jangka waktu tertentu.Untuk itu diperlukan suatu acuan sebagai pegangan bagi petani / pengolah dalam menghasilkan produk yang dipersyaratkan pasar. Seiring dengan meningkatnya tuntutan konsumen terhadap produk yang aman dan ramah lingkungan, maka acuan standar tersebut harus mengakomodasi prinsip penanganan pascapanen yang baik dan benar.

Kabupaten Bener Meriah adalah salah satu kabupaten di provinsi Aceh. Komoditas utama hasil bumi Kabupaten Bener Meriah adalah kopi. Dengan luas tanaman yang menghasilkan sebesar 43.565 Ha dan produksi sebanyak 29.357 ton pada tahun 2014 (BPS, 2017). Desa Petukel Blang
Jorong merupakan salah satu desa dari 32 desa yang terletak di wilayah Kecamatan Bandar Kabupaten Bener Meriah, dengan luas wilayah $120 \mathrm{Ha}$. Desa Petukel Blang Jorong memiliki jumlah penduduk 1450 jiwa dengan 420 kepala keluarga dengan klasifikasi laki-laki 690 jiwa dan perempuan 760 jiwa.

Kelompok tani BLJ Tani (Blang Jorong Tani) dan kelompok tani Buge Mujadi adalah dua kelompok tani petani kopi di Desa Petukel Blang Jorong yang menjadi masyarakat mitra kegiatan penerapan TTG.

Dari hasil temuan dan diskusi yang dilakukan tim pengabdian kepada masyarakat dengan kelompok tani, dapat dirumuskan beberapa permasalahan yang menjadi prioritas untuk diselesaikan, yaitu : (a) petani kopi sebagai masyarakat mitra masih terkendala dalam proses pengupasan kulit buah kopi, yang membutuhkan waktu yang lebih lama (pengupasan kulit buah masih manual menggunakan tenaga manusia untuk memutar alat pulper), perlunya biaya tambahan untuk memindahkan buah kopi dari kebun ke perumahan dan lingkungan proses pengupasan yang dapat mencemari lingkungan. Kulit buah kopi hasil pengupasan menjadi busuk dan berbau dalam jangka waktu lama, (b) masyarakat mitra belum mengenal teknologi pencucian. Selama ini pencucian biji kopi masih sangat tradisional sehingga membutuhkan waktu dan tenaga yang lebih banyak, (c) selama ini, proses pengupasan kulit ari kopi dilakukan di pabrik penggilingan besar. Hal mempunyai beberapa kelemahan, antara lain; tidak bisa untuk kapasitas kecil, penggilingan tidak setiap hari, kopi hasil penggilingan sering bercampur dengan pemilik lain, membutuhkan waktu membawa ke pabrik yang jaraknya cukup jauh, dan biaya penggilingan yang mahal. Oleh karena itu masyarakat mitra perlu sentuhan teknologi pengupasan kulit ari kopi dengan kapasitas kecil menengah dan konstruksi yang mobile.

Tujuan dari kegiatan penerapan TTG kepada masyarakat ini adalah memperkenalkan dan implementasi mesinmesin teknologi tepat guna pascapanen kopi (mesin pengupas kulit buah kopi sistem berjalan, mesin pencuci biji kopi dan mesin huller berjalan) kepada masyarakat petani kopi di Desa Petukel Blang Jorong Kecamatan Bandar Kabupaten Bener Meriah. 
Upaya ini dilakukan untuk meningkatkan pendapatan dan produktifitas masyarakat mitra (petani kopi) nantinya. Sasaran dari kegiatan penerapan TTG ini, antara lain: mempercepat hilirisasi mesin-mesin teknologi tepat guna pascapanen kopi yang dihasilkan oleh institusi Politeknik Negeri Lhokseumawe kepada masyarakat petani kopi di Kabupaten Bener Meriah disamping meningkatkan produktivitas, nilai tambah, kualitas maupun daya saing produk mesin-mesin teknologi tepat guna pascapanen kopi yang dihasilkan

Proses pengolahan kopi secara tradisional salah satu kendalanya adalah dalam hal pengupasan kulit biji kopi yang memakai waktu dan energi yang besar sehingga proses pengupasan kulit biji kopi dirasa kurang efisien. Selain itu hasil dari pengupasan kulit biji kopi kurang baik karena masih banyak biji kopi yang pecah setelah proses pengupasan. Jika industri kopi skala kecil dan menengah ini pertumbuhannya makin terpuruk karena persaingan yang tidak seimbang dengan produsen besar dan berskala nasional dan bahkan internasional (ekspor), karena didukung oleh teknologi canggih dari negara-negara maju lainnya.

Beberapa peneliti telah mengembangkan mesin pascapanen kopi untuk peningkatan produksi petani kopi. Widodo (2012) telah melakukan pengembangan mesin pengolahan kopi skala UKM di kabupaten Alor, Nusa Tenggara Timur. Syahrir (2013) telah mengembangkan mesin pengupas kulit buah kopi. Hasil rancangan mesin kopi tersebut di dapat dengan kecepatan putaran pengupas $152 \mathrm{rpm}$ dan kecepatan putaran pintu masuk $63 \mathrm{rpm}$ untuk mencapai kapasitas $10 \mathrm{~kg} /$ menit. Daya mesin yang di butuhkan untuk pengerak mesin dengan kapasitas $10 \mathrm{~kg} /$ menit adalah $24,24 \mathrm{~kW}$. Hasil pengujian menunjukan kualitas pengupasan kulit kopi 91\% (kopi basah) dan 96\% (kopi kering). Waktu yang di butuhkan untuk pengupasan yaitu 54 detik (kopi basah) dan 69\% detik (kopi kering).

Sukrisno (2011) telah melakukan evaluasi kinerja mesin pengupas kulit buah kopi basah tipe silinder horisontal. Pengupasan kulit kopi basah merupakan salah satu tahapan proses pengolahan kopi yang membedakan antara pengolahan kopi secara basah dengan kering. Pengupasan kulit kopi basah dan kontruksi mesin ini sangat beragam, dan secara umum di bedakan berdasarkan jumlah silinder pengupasnya. Hasil penelitiannya menunjukkan bahwa kapasitas mesin pengupas berdasarkan jumlah silinder pengupas. Mesin pengupas tipe silinder tungal dengan putaran optimum 308 rpm di peroleh kapasitas kerja $1.890 \mathrm{~kg} / \mathrm{jam}$ dengan $1 \%$ buah pecah, $9,2 \%$ kopi tanpa kulit $20 \%$ kulit terikut buah, dan $4,1 \%$ buah tidak terkupas. Untuk mesin pengupas tipe silinder ganda, pada putaran optimum $570 \mathrm{rpm}$ di peroleh kapasitas $3.000 \mathrm{~kg} / \mathrm{jam}$ dengan 5,4\% kopi tanpa kulit $15 \%$ berikut buah, dan $3 \%$ buah tidak terkupas. Sedangkan mesin pengupas tipe tiga silinder, pada putaran optimum $525 \mathrm{rpm}$ di peroleh kapasitas kerja $7.600 \mathrm{~kg} / \mathrm{jam}$ dengan 3,6\% kopi tanpa kulit, $6,7 \%$ kulit berikut buah, dan $1,8 \%$ buah tidak terkupas.

Indra (2017) dan Muzammir (2018) telah mengembangkan mesin-mesin TTG pascapanen kopi. Mesin kopi yang dikembangkan berupa rancangan model mesin pengupas kulit buah kopi berjalan dan mesin huller berjalan.

\section{METODE}

Metode yang digunakan dalam
pengabdian kepada masyarakat ini
menggunakan beberapa metode yaitu metode pendekatan fungsional, pelatihan dan pendampingan. Metode pendekatan fungsional dilakukan mulai dari indentifikasi masalah, pendekatan struktural dengan kelompok tani dan perangkat desa, perancangan dan fabrikasi mesin-mesin TTG.

Tahapan-tahapan yang akan dilakukan dalam penerapan mesin-mesin TTG pascapanen kopi kepada masyarakat Desa Petukel Blang Jorong kecamatan Bandar Kabupaten Bener Meriah, antara lain: (1) Melakukan indentifikasi permasalahan dan kebutuhan masyarakat mitra (proses ini telah dilakukan). Proses ini merupakan tahapan awal dalam pengelompokan permasalahan masyarakat; (2) Berkoordinasi dengan perangkat desa, kecamatan sampai kabupaten, terutama dengan pihak pihak terkait dengan kegiatan. Proses ini merupakan salah satu bentuk sosialisasi kegiatan kepada Pemerintah Daerah; (3) Melakukan perancangan dan pembuatan mesin-mesin TTG pascapanen kopi sesuai dengan 
permasalahan yang telah disepakati untuk diselesaikan; (4) Implementasi atau penerapan mesin-mesin TTG pascapanen kopi yang telah difabrikasi dalam bentuk pelatihan penggunaan mesin dan teknik perawatan; (5) Pedampingan operasional selama kegiatan yang akan dilakukan secara berkala. Proses ini berguna untuk mengatasi permasalahan yang terjadi selama penerapan teknologi ke mitra; (6) Evalausi akhir, berguna untuk melihat tingkat keberlanjutan kegiatan nantinya

Pada kegiatan program penerapan TTG kepada masyarakat petani kopi desa Petukel Blang Jorong kecamatan Bandar Kabupaten Bener Meriah, akan diterapkan mesin-mesin TTG pascapanen kopi, yaitu mesin pengupas kulit buah kopi berjalan, mesin pencuci biji kopi dan mesin huller berjalan. Adapun desain mesin yang akan difabrikasi dan diterapkan diperlihatkan pada gambar 1 - 3 .

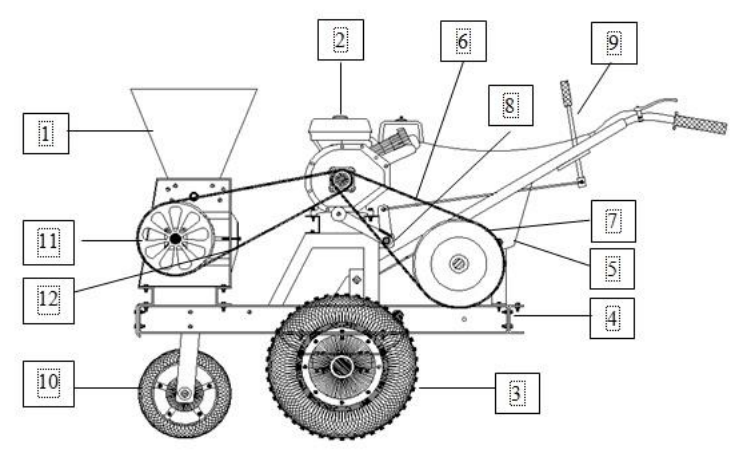

Gambar 1. Skema mesin pengupas kulit kopi berjalan

\section{Keterangan:}

1. Alat pulper

$\begin{array}{ll}\text { 7. } & \text { Puli gearbox } \\ \text { 8. } & \text { Roda pengencang } \\ \text { 9. } & \text { Handle roda } \\ & \text { pengencang } \\ \text { 10. } & \text { Roda depan } \\ \text { 11. } & \text { Puli mesin pengupas } \\ \text { 12. } & \text { Sabuk mesin } \\ & \text { pengupas }\end{array}$

3. Roda

4. Rangka

5. Gearbox

6. Sabuk gearbox
2. Motor penggerak

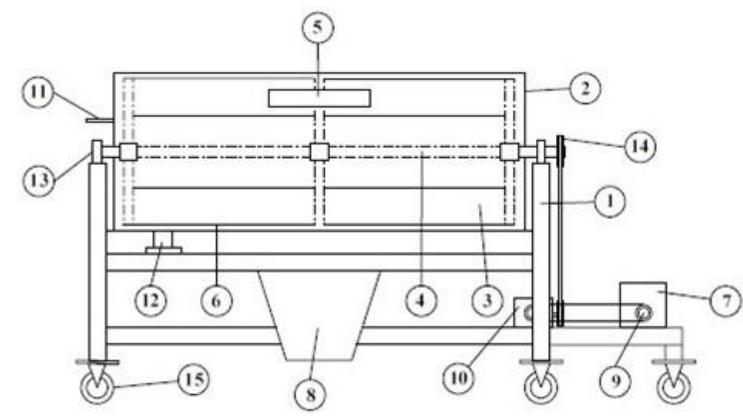

Gambar 2. Skema mesin pencuci biji kopi type bacth

Keterangan:

$\begin{array}{llll}\text { 1. } & \text { Rangka } & 9 . & \text { Puli penggerak } \\ \text { 2. } & \text { Tabung pencuci } & \text { 10. } & \text { Gear box } \\ \text { 3. } & \text { Baling pengaduk } & \text { 11. } & \text { Handle pemutar } \\ \text { 4. } & \text { Poros pengaduk } & \text { 12. } & \text { Kran } \\ \text { 5. } & \text { Gearbox } & \text { 13. } & \text { Bantalan } \\ \text { 6. } & \text { Sabuk gearbox } & \text { 14. } & \text { Puli } \\ \text { 7. } & \text { Motor penggerak } & 15 & \text { Roda } \\ \text { 8. } & \text { Saluran keluar } & & \end{array}$

8. Saluran keluar

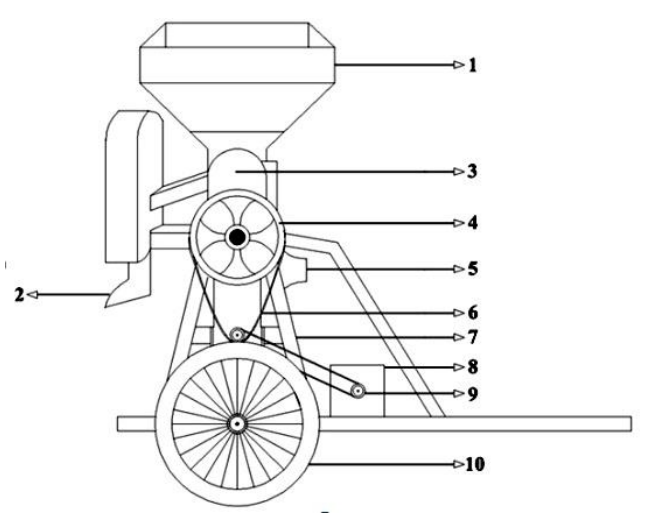

Gambar 3. Skema mesin pengupas biji kopi (huller) berjalan

Keterangan:

$\begin{array}{llll}\text { 1. } & \text { Hopper } & 6 . & \text { Sabuk } \\ \text { 2. } & \text { Saluran keluar biji } & 7 . & \text { Rangka } \\ \text { 3. } & \text { Huller } & 8 . & \text { Motor penggerak } \\ \text { 4. } & \text { Puli } & 9 . & \text { Puli penggerak } \\ \text { 5. } & \text { Saluran keluar kulit } & 10 & \text { Roda } \\ & \text { ari }\end{array}$

Evaluasi dilaksanakan oleh tim secara berkala yaitu pada bulan pertama setelah penerapan TTG dan pada akhir kegiatan nantinya. Evaluasi pada tahap awal berguna melihat kendala yang dihadapi setelah implementasi program. Sedangkan evaluasi akhir dilakukan untuk melihat tingkat keberhasilan dan keberlanjutan program setelah masa kegiatan berakhir. Indikator evaluasi berupa; 
a. Melihat tingkat kebutuhan (urgensi) TTG yang diterapkan

b. Peran masyarakat mitra dalam kegiatan

c. Kemampuan masyarakat mitra dalam mengoperasikan TTG

d. Kemampuan masyarakat mitra dalam melakukan perawatan dan perbaikan atau mengatasi kendala selama pengoperasian TTG

e. Peningkatan produktivitas masyarakat mitra
Luaran yang dihasilkan dari kegiatan penerapan mesin-mesin TTG pascapanen kopi kepada masyarakat Desa Petukel Blang Jorong Kecamatan Bandar Kabupaten Bener Meriah berupa mesin-mesin teknologi tepat guna pascapanen kopi. Gambar 4 memperlihatkan paket produk teknologi tepat guna mesin-mesin pascapanen kopi yang terdiri dari dua unit mesin pengupas kulit buah kopi sistem berjalan, satu unit mesin pencuci biji kopi dan satu unit mesin huller berjalan, yang telah dibuat dan siap diimplementasikan kepada petani kopi di Desa Petukel Blang Jorong Kecamatan Bandar Kabupaten Bener Meriah.

\section{HASIL DAN PEMBAHASAN}

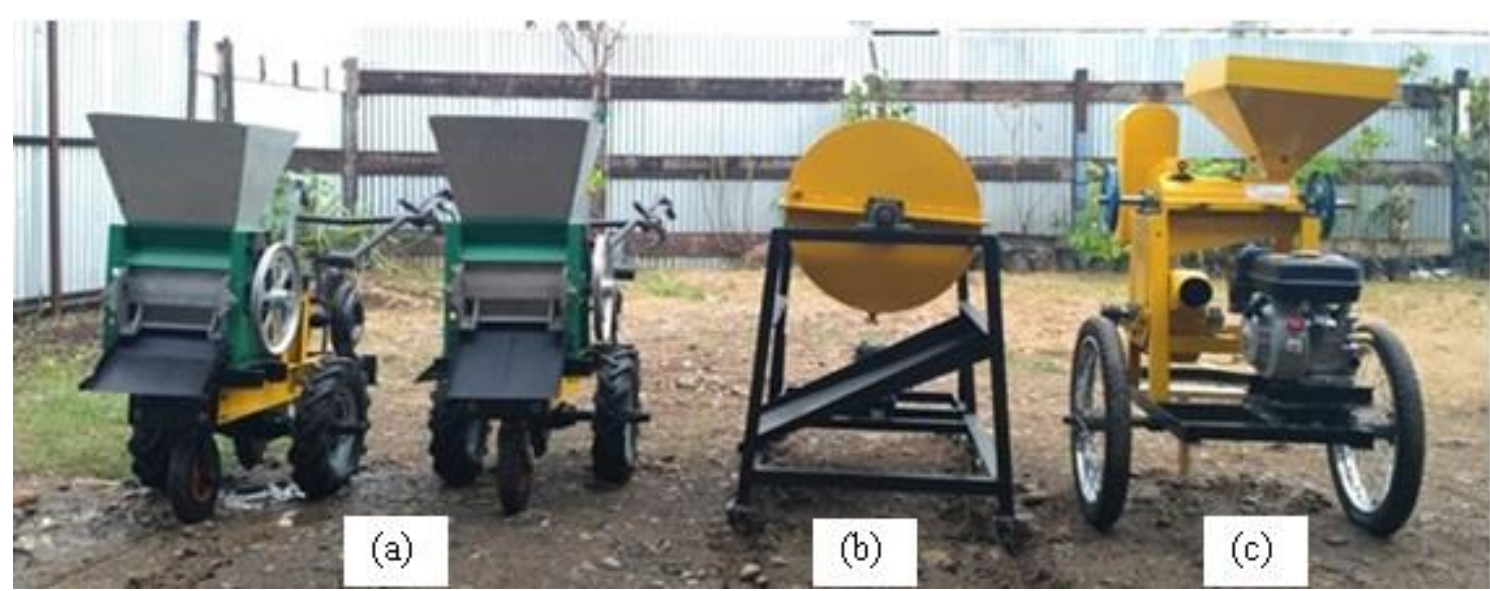

(a) Mesin pengupas kulit kopi berjalan (b) Mesin pencuci biji kopi

(c) Mesin pengupas biji kopi (Huller) berjalan

Gambar 4. Mesin-mesin teknologi tepat guna pascapanen kopi

\section{Mesin Pengupas Kulit Buah Kopi Berjalan}

Proses pengolahan pascapanen kopi diawali dengan pengupasan kulit buah dengan mesin mengupas (pulper). Konstruksi mesin pegupas kulit buah kopi yang telah ada selama ini memiliki kapasitas yang berat dan tidak mudah untuk dipindah-pindahkan (tidak mobile). Hal menyebabkan proses pengupasan kulit menjadi terbatas pada lokasi tertentu. Mesin ini mempunyai keunikan dan keunggulan dibandingkan produk yang telah beredar dipasaran. Mesin ini bersifat mobile, dapat digunakan dimana saja dan dapat dengan mudah dipindahkan dari satu lokasi ke lokasi lain. Mesin dapat digunakan di kebun petani kopi yang kebanyakan berada di dataran tinggi (pegunungan) atau lerenglereng perbukitan. (Gambar 5).
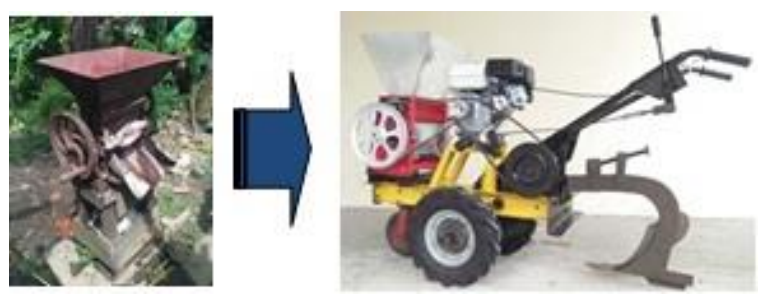

Gambar 5. Kondisi sebelum dan setelah pada proses pengupasan buah kopi

Dengan adanya mesin ini biji kopi tidak perlu dibawa turun ke rumah untuk dikupas kulitnya, akan tetapi dapat langsung mengupas kulit kopi di lokasi kebun. Dengan adanya mesin pengupas kulit kopi berjalan ini nantinya diharapkan akan dapat mempermudah dan mempercepat proses pengupasan itu sendiri. Mesin pengupas dengan kapasitas $80-100 \mathrm{~kg}$ buah kopi per 
jam digerakkan dengan motor bakar bensin 5,5 HP. Mesin ini sangat cocok digunakan oleh petani secara individu atau kelompok tani. Selain berfungsi sebagai pengupas kopi, mesin pengupas kulit buah kopi berjalan dapat juga digunakan sebagai mesin bajak tanah atau penggembur tanah diarea kebun kopi.

\section{Mesin Pencuci Biji Kopi}

Pencucian bertujuan untuk menghilangkan sisa lendir hasil fermentasi yang masih menempel di kulit tanduk. Untuk kapasitas kecil, pencucian dapat dikerjakan secara manual di dalam bak atau ember (kapasitas 5-10 kg), sedang untuk kapasitas menengah ke atas (besar) perlu dibantu dengan mesin pencucian. Kondisi awal mitra belum mengenal mesin cuci kopi. Proses pencucian biji kopi yang dilakukan selama ini masih manual dan tradisional, sehingga kurang efektif dan efesien, terlebih jika pencucian dalam jumlah yang banyak. Gambar 6 memperlihatkan proses pencucian sebelum dan setelah adanya teknologi.
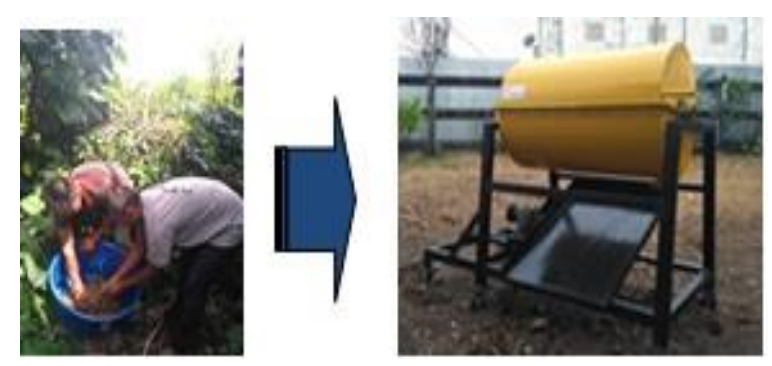

Gambar 6. Kondisi sebelum dan setelah pada proses pencucian biji kopi

Mesin pencuci biji kopi tipe batch yang siap diterapkan kepada petani kopi untuk mempermudah dan meningkatkan produktivitas biji kopi yang siap jemur. Mesin ini mempunyai wadah pencucian berbentuk silinder. Mesin ini dirancang untuk kapasitas kecil dan konsumsi air pencuci yang terbatas. Biji kopi sebanyak 10-20 kg dimasukkan ke dalam silinder lewat saluran masuk dan kemudian dimasukan sejumlah air. Kebutuhan air pencuci berkisar antara $2-3$ $\mathrm{m}^{3}$ per ton biji kopi. Mesin pencuci biji kopi menggunakan daya 5,5 HP. Proses pencucian dilakukan selama 2 sampai 3 menit dengan pengulangan sebanyak 2 kali. Mesin ini mempunyai kapasitas pencuncian kopi 100$150 \mathrm{~kg}$ per jam.

\section{Mesin Pengupas Biji Kopi (Huller) Berjalan}

Pengupasan ditujukan untuk memisahkan biji kopi dari kulit tanduk. Hasil pengupasan disebut biji kopi beras. Kondisi awal dari petani kopi (mitra) belum mengenal mesin huller kapasitas kecil, sehingga proses pengupasan kulit ari kopi harus dalam jumlah kecil juga harus dibawa ke pabrik pengggilingan yang besar. Permasalahannya adalah: (a) Tidak bisa dilakukan proses pengupasan dalam jumlah yang kecil; (b) Mudah tercampur dengan biji kopi orang lain; (c) Jarak pabrik pengupasan yang jauh, sehingga butuh biaya transportasi; (d) Waktu pengupasan di pabrik besar yang tidak setiap hari, sehingga memerlukan waktu tunggu.

Mesin pegupas yang biji kopi yang telah diproduksi dan telah diterapkan kepada masyarakat petani kopi diperlihatkan pada Gambar 7. Mesin pengupas biji kopi yang diproduksi mempunyai keunikan pada mobilisasi pengoperasiannya (mudah dipindah-pindahkan), sehingga proses pengupasan akan lebih efektif dan dapat digunakan untuk kapasitas kecil sampai menengah Mesin pengupas biji kopi mempunyai kapsitas produksi $50-100 \mathrm{~kg}$ per jam. Mesin pengupas biji kopi ini dapat menggunakan sepeda motor dalam proses perpindahannya.
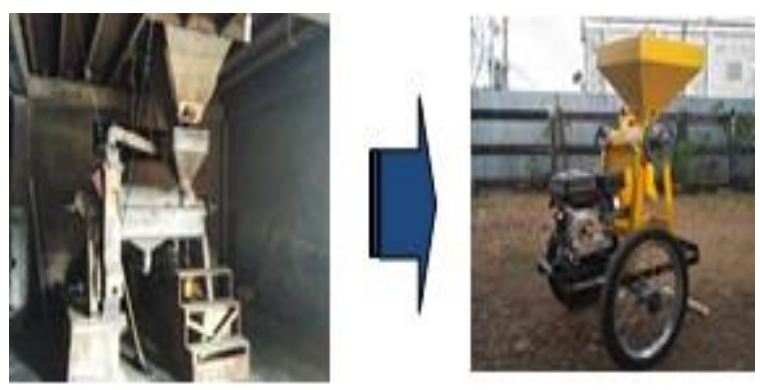

Gambar 7. Kondisi sebelum dan setelah pada proses pengupasan kulit ari biji kopi

Gambar 8 memperlihatkan foto kegiatan serah terima mesin kepada kelompok tani, yang disaksi juga oleh kepala desa dan camat kecamatan Bandar. 
Mawardi, Hanif, Zaini, Abidin. Penerapan Teknologi Tepat

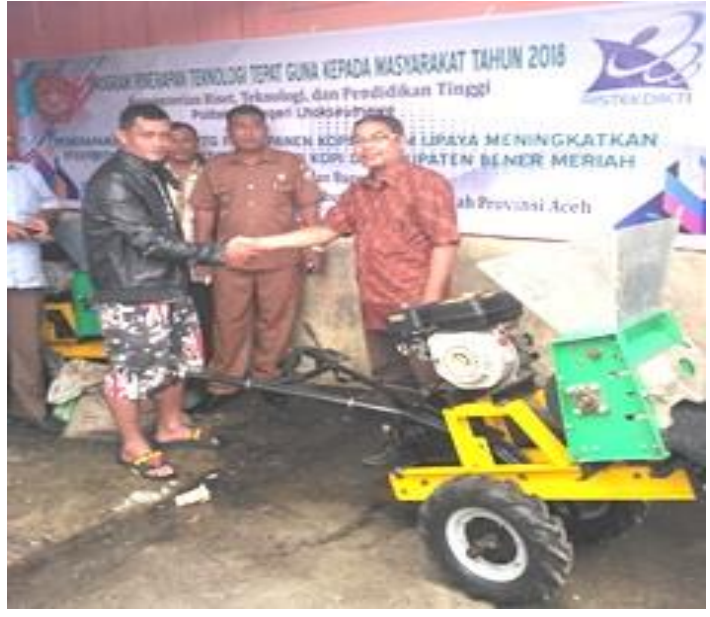

Gambar 8. Serah terima mesin kepada kelompok tani

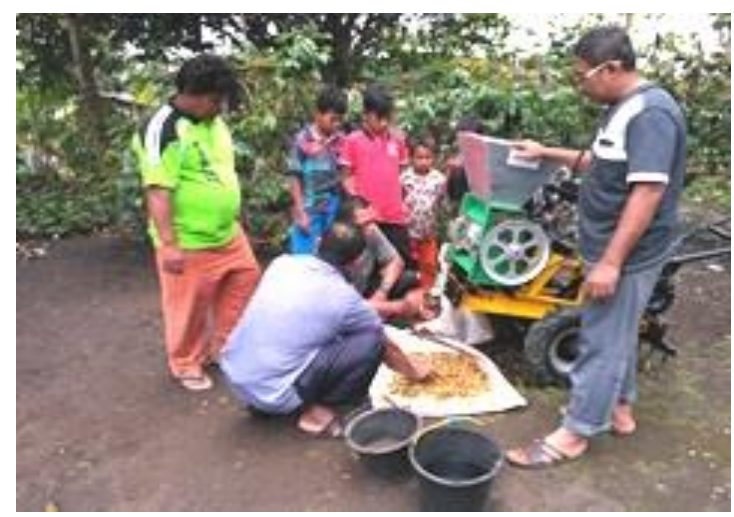

Gambar 9. Kegiatan pendampingan awal

Gambar 9 memperlihatkan kegiatan pedampingan awal berupa pemberian teknik pengoperasian mesin dan sistem perawatannya.

Kelompok tani BLJ Tani dan kelompok tani Buge Mujadi yang merupakan mitra kegiatan mempunyai luas perkebunan kopi, masing-masing $9 \mathrm{Ha}$ dan $12 \mathrm{Ha}$. Dalam setahun kedua kelompok tani bisa memanen kopi sebanyak 2 kali. Sedangkan untuk panen kecil, petani memanen biji kopinya 2 minggu sekali. Dalam setahun petani kopi dapat menghasilkan $3.000 \mathrm{~kg} / \mathrm{Ha}$ buah kopi basah (gelondong). Kebanyakan anggota kelompok tani menjual hasil panennya dalam jumlah yang kecil dan masih dalam bentuk kopi gelondong, dengan harga Rp. 8.000,- s.d $10.000,-$ per kg. Hal ini dikarenakan kebanyakan petani kopi dikedua kelompok tani belum memiliki mesin pengupas kulit buah kopi.

Dari pengujian pada saat implementasi mesin-mesin TTG pascapanen kopi kepada kelompok tani dihasilkan beberapa peningkatan pada proses pengupasan, pencucian dan pengupas kulit ari. Tabel 1 memperlihat hasil pengujian untuk $100 \mathrm{~kg}$ buah kopi basah dan kering yang diproses sebelum dan setelah penerapan mesin-mesin TTG.

Tabel 1. Indikator keberhasilkan penerapan TTG

\begin{tabular}{|c|c|c|c|}
\hline Variabel & $\begin{array}{c}\text { Sebelum } \\
\text { penerapan } \\
\text { (menit) }\end{array}$ & $\begin{array}{c}\text { Setelah } \\
\text { penerapan } \\
\text { (menit) }\end{array}$ & $\begin{array}{c}\text { Selisih } \\
\text { waktu } \\
\text { (menit) }\end{array}$ \\
\hline $\begin{array}{c}\text { Pengupasan } \\
\text { kulit buah }\end{array}$ & 90 & 50 & 40 \\
\hline $\begin{array}{c}\text { Pencucian } \\
\text { biji }\end{array}$ & 75 & 65 & 10 \\
\hline $\begin{array}{c}\text { Pengupasan } \\
\text { kulit ari }\end{array}$ & '- & 100 & 100 \\
\hline
\end{tabular}

Dari Tabel 1 terlihat proses pascapanen kopi terjadi penghematan waktu proses. Selain waktu proses, penerapan TTG telah dapat menekan biaya penurunan buah kopi dari kebun ke lokasi pengupasan (kampung) dan juga petani telah dapat memproses biji kopi kering dalam jumlah yang kecil tanpa harus membawa ke pabrik penggilingan yang besar.

Penerapan mesin-mesin TTG juga telah merubah prilaku menjual hasil kebun dalam bentuk buah kopi basah (gelondong) menjadi menjual dalam bentuk biji kering. Peningkatan proses ini secara tidak langsung meningkatkan nilai tambah dari produk yang dihasilkan. Keberhasilan pengembangan teknologi pascapanen tergantung dari keberhasilan sistem inovasi teknologi dan pendampingan (Stathers, 2013).

Penerapan mesin-mesin TTG pascapanen kopi di Desa Petukel Blang Jorong kecamatan Bandar Kabupaten Bener Meriah mempunyai dampak ekonomi dan sosial. Dampak ekonomi ditunjukan dengan meningkatnya produktifitas kelompok tani kopi dalam menghasilkan produk kopi siap jual, meningkatnya nilai tambah produk, dan pemantapan daya saing terhadap produk sejenis. Semua variabel tersebut pada akhirnya akan meningkatkan pendapat dan kesejahtera petani kopi. Hal ini sesuai dengan kebijakan pemerintah dalam pengembangan teknologi pascapanen kopi (Mayrowani, 2013). 
Dampak ekonomi tidak terlepas dari kemudahan petani kopi dalam melakukan proses pascapanen kopi setelah penerapan mesin-mesin TTG pascapanen kopi. Petani kopi telah mengenal dan menggunakan teknologi proses pengolahan pascapanen kopi.

Dukungan dari berbagai faktor, seperti program pengabdian masyarakat dalam bentuk penerapan TTG pascapanen kopi dan bantuan alsinta dari pemerintah, memungkinkan petani menangani pascapanen kopi seperti pengupasan kulit buah kopi, pencucian, pengupasan kulit HS dan sortasi dengan mesin-mesin teknologi tepat guna sesuai dengan kemajuan teknologi. (Mayrowani, 2012).

Penerapan mesin-mesin TTG pascapanen kopi telah menyebabkan terjadinya perubahan sosial masyarakat petani kopi dalam menciptakan cara dan sikap masyarakat petani dalam melakukan proses produksi hasil perkebunannya. Dampak sosial yang dirasakan diantaranya adalah petani kopi telah mengenal teknologi pascapanen kopi yang mempermudah proses pengolahan kopi pada fase pascapanen. Selain itu proses penerapan dan pemanfaatan teknologi pascapanen menjadi sangat penting agar mesin-mesin TTG dapat diadopsi dan dikembangkan petani kecil.

\section{SIMPULAN DAN SARAN}

Dari hasil kegiatan penerapan TTG kepada masyarakat petani kopi, telah berhasil diproduksi dan diimplementasikan mesinmesin TTG pascapanen kopi yang terdiri dari dua unit mesin pengupas kulit kopi berjalan (pulper mobile), satu unit mesin pencuci biji kopi type bacth, dan satu unit mesin pengupas biji kopi berjalan (huller mobile) kepada petani kopi di Desa Petukel Blang Jorong kecamatan Bandar Kabupaten Bener Meriah.

Melalui program pengabdian ini, petani kopi di Desa Petukel Blang Jorong kecamatan Bandar Kabupaten Bener Meriah telah mengenal teknologi pengolahan buah kopi pascapanen.

Dari hasil implementasi mesin-mesin TTG pascapanen kopi, telah terjadi peningkatan produktifitas mencapai $30 \%$ terhadap proses pascapenen yang meliputi proses pengupasan kulit basah, pencucian biji kopi dan pengupasan kulit ari biji kopi kering.

Keberlanjutan pemanfaatan teknologi pascapanen kopi harus terus didorong agar berdampak pada peningkatan kesejahteraan petani kopi. Pengembangan teknologi pascapanen memerlukan kerja sama pemerintah daerah dan lembaga penelitian dan pengembangan dalam membangun keterkaitan institusional dan fungsional dari sejumlah kelembagaan terkait di lapangan. Penerapan teknologi tepat guna pascapanen kopi saat ini masih belum merata, oleh karena itu perlunya penyebaran informasi tentang teknologi tepat guna pascapanen kopi secara intensif.

\section{DAFTAR RUJUKAN}

Anonim. (2017). Kopi (online) https://www. indonesia-investments.com/id/bisnis/ komoditas/kopi/item186? (diakses 9 Mei 2017).

Anonim. (2017). Luas Perkebunan Kopi (online). https://benermeriahkab.bps. go.id/subject/54/perkebunan.kopi.htm 1 (diakses 2 Februari 2018)

Chandra, D., R.H. Ismono dan E. Kasymir. (2013). Prospek Perdagangan Kopi Robusta Indonesia di Pasar Internasional. Jurnal ilmu-ilmu Agribisnis (JIIA), Vol 1 No. 1 Tahun 2013. Fakultas Pertanian, Universitas Lampung.

Indra, M., Nurdin, Zulkarnaini. (2017). Inovasi Mesin-Mesin Teknologi Tepat Guna Pascapanen Kopi. Prosiding Seminar Nasional Pengabdian Kepada Masyarakat 2017 vol. 2 no. 2 Tahun 2017

Mayrowani H., (2013). Kebijakan Penyediaan Teknologi Pascapanen Kopi dan Masalah Pengembangannya. Forum Penelitian Agro Ekonomi, Vol 31, No. 1, Juli 2013. Bogor

Mayrowani, H., D.K.S. Swastika, R.N. Suheti dan Supadi. (2012). Kajian Kebijakan Pascapanen: Analisis Kebutuhan, Evaluasi Program, dan Dampak Penerapan Teknologi Pascapanen. Laporan Penelitian, Pusat Sosial Ekonomi dan Kebijakan Pertanian. Badan Penelitian dan Pengembangan Pertanian. Bogor. 
Mawardi, Hanif, Zaini, Abidin. Penerapan Teknologi Tepat

Muzammir, Indra, M., Samsul, B.. (2018). Modifikasi Konstruksi Mesin Pengupas Kulit Ari Kopi Dengan Daya $5 \mathrm{Hp}$. Jurnal Mesin Sains Terapan, vol.2, no.1 Tahun 2018

Sukrisno, W., Ahmad, S. dan Mulato. (2011). Kinerja Mesin Pengupas Kulit Buah Kopi Basah Tipe Tiga Silinder Horisontal. Jurnal Pelita Perkebunan, Volume 27, Nomor 1, Edisi April 2011.
Syahrir, A. 2013. Perancangan Mesin Pengupas Kulit Kopi. Proceeding Seminar Nasional Tahunan Teknik Mesin XII (SNTTM XII) \& Thermofluid IV Universitas Lambung Mangkurat (Unila), Bandar Lampung, 23-24 Oktober 2013.

Thurmizi. (2014). Potensi dan Pengembangan Kopi di Aceh. Indonesia International Coffee Symposium 2014, Banda Aceh 1922 November 2014.

Widodo, P. (2012). Pengembangan Mesin Pengolahan Kopi Skala UKM di Kabupaten Alor, Nusa Tenggara Timur. (online). http://www.pkpp.ristek. go.id (diakses 12 Mei 2016). 